\title{
TINJAUAN HUKUM ISLAM TERHADAP PRAKTEK UTANG PIUTANG ANGGOTA KELOMPOK TANI (STUDI KASUS DI DESA KARANG BUDI KECAMATAN GAPURA KABUPATEN SUMENEP).
}

\author{
Eka Ferdiansyah \& Djoko Subagyo \\ Email: Ekaferdiansyah@yahoo.com
}

\begin{abstract}
Abstrak
Penelitian lapangan dilakukan di Desa Karang Buddhi, Kecamatan Gapura, Kabupaten Sumenep dengan tujuan menjawab bagaimana praktik utang piutang yang dimiliki oleh kelompok tani Anyar Tani di Karang buddhi Desa, Kecamatan Gapura, Kabupaten Sumenep? Dan bagaimana tinjauan hukum Islam tentang praktik hutang dalam kelompok petani Anyar Tani di Desa Karang buddhi, Kecamatan Gapura, Kabupaten Sumenep? Metode yang digunakan dalam penelitian ini adalah metode kualitatif. adalah paradigma penelitian untuk menggambarkan peristiwa, fenomena, perilaku orang atau situasi di tempat tertentu secara detail dan mendalam dalam bentuk narasi. Jenis penelitian ini adalah penelitian lapangan (field reseacrh). Pendekatan yang digunakan adalah studi kasus adalah satu jenis pendekatan kualitatif yang meneliti "kasus" tertentu dalam konteks atau pengaturan kehidupan nyata kontemporer. Studi kasus adalah jenis penelitian mendalam tentang individu, satu kelompok, satu organisasi, satu program aktivitas, dan seterusnya dalam waktu tertentu.

Hasil penelitian menemukan bahwa praktek hutang Kelompok Tani Anyar Tani di Desa Karang Buddhi menunjukkan bahwa jumlah uang pinjaman tidak sesuai dengan kontrak. Unsur mencari keuntungan bertentangan dengan sistem utang piutang, karena pada dasarnya memberikan bantuan timbal balik, tidak semata-mata untuk tolong menolong. Ada sistem riba 'dalam praktik utang piutang Kelompok Tani di Desa Karang Buddhi, karena ada lebih banyak pengembalian yang disepakati dan dibutuhkan oleh peminjam, meskipun untuk tujuan sosial. Tidak dibenarkan untuk mengambil keuntungan dan bertindak atas nama kepentingan sosial dengan cara yang dilarang dan bertentangan dengan syariat. jika bertujuan untuk memberikan pinjaman kepada mereka yang membutuhkan, itu harus tetap mempertimbangkan unsur-unsur ta'āwun (bantuan), bukan mengambil keuntungan.
\end{abstract}

Kata kunci: Hukum Islam, Qard, Kelompok Tani.

\section{PENDAHULUAN}

Masyarakat pedesaan merupakan masyarakat yang memenuhi kebutuhan hidupnya dengan memanfaatkan sumber daya alamnya. Perpaduan antara manusia dan lingkungan yang ditimbulkan oleh unsur-unsur Fisiografi, sosial, ekonomi dan kultur yang saling berinteraksi. Masyarakat desa mendasarkan diri mereka pada tingkat pendidikan dan tingkat teknologi yang belum bekembang. Dalam memenuhi kebutuhan mereka, masyarakat di pedesaan memanfaatkan kekayaan alam yang dimiliki desa tersebut. Tanah-tanah 
yang produktif, hewan ternak dan sumber mata air yang bersih. Namun tak semua bisa dimanfaatkan sampai sekarang. lahan yang semakin sempit lantaran pabrikpabrik berdiri, air bersih tercemar oleh limbahnya, bahkan hewan ternak terserang macam-macam penyakit. Hal ini mendorong masyarakat pedesaan untuk membentuk kelompok-kelompok kecil untuk mengatasi permaslahan tersebut. Dasar kesamaan nasib menjadi alasan utama mereka berkelompok. Prinsip gotong royong adalah menjadi pola dasar kerja kelompok mereka.

Masyarakat adalah pergaulan hidup manusia, sehimpunan yang hidup bersama dalam suatu tempat dengan ikatan - ikatan antara aturan tertentu. Dalam artian masyarakat merupakan sekumpulan manusia yang telah lama hidup bersama dalam daerah tertentu dan memiliki aturanaturan untuk mengatur tata hidup mereka. Aturan-aturan tersebut dibuat untuk menjaga dan mengatur tindakan yang terjadi akibat kontak langsung antar individu. Hasrat yang ada seperti pemenuhan kebutuhan jasmani dan rohani atau kebutuhan primer maupun kebutuhan sekunder. Dorongan-dorongan tersebut yang menjadi dasar perilaku manusia untuk melakukan segala macam cara dalam memenuhi kebuthan hidupnya. Ditambah perkembangan jaman yang membuat manusia semakin sulit dalam memenuhi kebutuhannya.

Seiring perkembangan teknologi, perekonomian masyarakat semakin berkembang pesat. dalam kemudahan yang diberikan oleh kemajuan teknologi memaksa masyarakat berlomba-lomba memenuhi kebutuhannya dengan cepat dan bebas. segala cara dengan mudah dilakukan oleh masyarakat dengan memanfaatkan kemajuan teknologi. hal ini membuat masyarakat yang tak mampu mengikuti perkembangan dan pesatnya kemajuan teknologi semakin tertinggal. secara tidak langsung masyarakat membentuk kelompok-kelompok berdasarkan kemampuan dalam memanfaatkan kemajuan ilmu pengetahuan dan teknologi. Keberadaan kelompok di masyarakat ini sebagai bentuk organisasi yang didirikan oleh orang perseorangan atau kelompok, yang diharapkan dapat memenuhi aspirasi dan kebutuhan bersama di bidang ekonomi, sosial, dan budaya sesuai dengan nilai dan prinsip yang memiliki kontribusi bagi pertumbuhan ekonomi di suatu daerah. Pertumbuhan ekonomi menjadi indikator yang dapat digunakan untuk menilai keberhasilan pembangunan suatu daerah dalam periode waktu tertentu.

Islam sebagai agama telah mengatur segala urusan dalam kehidupan manusia mengenai perkara utang piutang. Konsep utang piutang yang ada dalam Islam pada dasarnya adalah untuk memberikan kemudahan dan saling tolong menolong bagi orang yang sedang kesusahan. namun pada jaman sekarang, konsep muamalah telah bercampur aduk serta keluar dari konsep islam. Hal ini sedikit demi sedikit mulai menggeser, bahkan bisa menghilangkan konsep muamalah Islam itu sendiri. Oleh karena itulah, perkara utang piutang ini penting untuk diketahui oleh umat Islam agar nantinya bisa melaksanakan kegiatan muamalah sesuai dengan yang telah disyariatkan oleh Allah SWT.

Menurut Hukum Syara', para ahli fiqh mendefinisikan Qardh sebagai berikut: 1) Menurut pengikut Madzhab Hanafi, Ibn Abidin mengatakan bahwa qardh adalah suatu pinjaman atas apa yang dimiliki satu orang lalu diberikan kepada yang lain kemudian dikembalikan dalam kepunyaannya dalam baik hati; 2) Menurut Madzhab Maliki, Qardh adalah Pembayaran dari sesuatu yang berharga untuk pembayaran kembali tidak berbeda atau setimpal; 3) Menurut Madzhab Hanbali, Qardh adalah pembayaran uang ke seseorang siapa yang akan memperoleh manfaat dengan itu dan kembalian sesuai dengan padanannya; 4) Menurut Madzhab Syafi'i, Qardh adalah Memindahkan kepemilikan sesuatu kepada seseorang, 
disajikan ia perlu membayar kembali kepadanya ${ }^{1}$. disinalah pentingnya peran lembaga keuangan koperasi dalam membantu para petani untuk menjalankan, memperluas dan mengembangkan kegiatan pertaniannya melalui pemberian bantuan pembiayaan.

Warisno (2002) mengelempokkan kelembagaan kedalam dua pengertian yaitu institute dan institusi. institute menunjuk pada kelembagaan formal misalnya organisasi, badan dan yayasan mulai dari tingkat keluarga, rukun keluarga, desa sampai pusat, sedangkat institusi merupakan kumpulan normanorma atau nilai-nilai yang mengatur prilaku manusia dalam memenuhi kebutuhannya $^{2}$. dari pengertian kelembagaan tersebut maka yang dimaksud dengan kelembagaan dalam sistem usaha tani adalah lembaga kelompok tani. dalam memajukan usaha tani perlu dilakukan analisis kelembagaan untuk menelaah kinerja kelompok tani. menurut Taryono analisis kelembagaan dalam bidang pertanian adalah analisis yang ditujukan untuk memperoleh diskripsi mengenai fenomena sosial ekonomi pertanian yang berkaitan dengan hubungan antar dua atau lebih pelaku interaksi sosial ekonomi, yang mencakup aturan-aturan yang berlaku dan disepakati bersama oleh para pelaku interaksi, dinamika prilaku yang ditunjukkan oleh pelaku interaksi disertai dengan analisis mengenai hasil akhir yang diperoleh dari hasil interaksi ${ }^{3}$.

Sesuai dengan apa yang diamanatkan menurut peraturan

${ }^{1}$ Farid Budiman, Karakteristik Akad Pembiayaan Al-Qardh Sebagai Akad Tabarru', Volume 28 No 3 (September - Desember 2013), 410.

${ }^{2}$ Suharyon dan Busyra BS, Kinerja Kelompok Tani Dalam Sisten Usaha Tani Padi Lahan Sub Optimal dan Metode Pemberdayaannya (Studi Kasus Pada Kegiatan Padi Sawah di Lahan Sub Optimal Kab. Tanjung Jabung Timur Jambi, Vol.18 No.1 (Januari-Juni, 2016), 78.

${ }^{3}$ Ibid., perundang-undangan Nomor 19 Tahun 2013 Tentang Perlindungan dan Pemberdayaan Petani, pasal 69 menyatakan bahwa Pemerintah dan pemerintah daerah sesuai dengan kewenangannya, berkewajiban mendorong dan memfasilitasi terbentuknya kelembagaan petani dan kelembagaan ekonomi petani. Dalam Pasal 1 dinyatakan pengertian kelembagaan ekonomi petani (KEP) sebagai lembaga yang melaksanakan kegiatan usaha tani yang dibentuk oleh, dari dan untuk petani, guna meningkatkan produktivitas dan efisiensi usaha tani, baik yang berbadan hukum maupun yang tidak berbadan hukum. Namun Undang-Undang Nomor 23 Tahun 2014 tentang pemerintah daerah, menyatakan setiap lembaga, kelompok, atau organisasi yang menerima dana hibah dari pemerintah harus berbadan hukum.

Kelompok tani bisa berbadan hukum setelah unit produksinya berkembang menjadi kelembagaan ekonomi petani (KEP) berupa badan usaha milik petani (BUMP). Dalam Peraturan Menteri Pertanian Nomor 82/Permentan/OT.140/8/2013 Tentang Pedoman Pembinaan Kelompok tani dan Gabungan Kelompok Tani (Gapoktan) adalah kumpulan petani/peternak/pekebun yang dibentuk atas dasar kesamaan kepentingan; kesamaan kondisi lingkungan sosial, ekonomi, sumberdaya; kesamaan komoditas; dan keakraban untuk meningkatkan dan mengembangkan usaha anggota.

Kelompok tani dibentuk berdasarkan surat keputusan dan dimaksudkan menjadi wadah komunikasi antar petani, serta antar petani dengan kelembagaan terkait dalam proses alih teknolotgi. Contoh kecil seperti kelompok tani yang ada di desa karang budi kecamatan gapura kabupaten Sumenep ini. Bermula dari kelompok tani yang hanya membantu penyaluran pupuk, kini merambah kesektor koprasi simpan pinjam untuk anggota kelompoknya. Hal ini dipicu karena masyarakat di desa karang 
budi kecamatan gapura kabupaten Sumenep didominasi oleh para petani dengan tingkat perekonomian yang sangat rendah. sehingga masyarakat mengalami kesulitan dalam mencari modal untuk kebutuhan pertaniannya seperti pembelian bibit unggul, pembelian pupuk bahkan modal produksi pertaniannya. Adapaun masyarakat yang memiliki lahan persawahan sendiri memilih untuk bekerja sama paruh hasil dalam sektor pertanian. Hal ini mendorong masyarakt untuk membentuk sebuah Koprasi kelompok tani guna membantu masyarakat dalam memenuhi biaya produksi pertaniannya dengan menyediakan jasa utang piutang bagi anggota. Kelompok tani tersebut mereka beri nama kelompok Anyar Tani. Didirikan sejak tahun 90 an dengan jumlah anggota 10 orang. Hingga sampai saat ini beranggotakan 32 orang yang diketuai oleh bapak Umar.

Penduduk Desa Karang Buddhi Kecamatan Gapura yang menotabene mayoritas muslim memiliki landasan kuat tentang pentingnya koperasi tanpa mengesampingkan syariat Islam. Namum dalam praktiknya, koperasi yang ada di Desa Karang Buddhi Kecamatan Gapura, pada saat sekarang ini menggunakan sistem konvensional, yang dinilai oleh sebagian masyarakat masih terdapat riba. Dalam hal ini praktek tentang qard juga disinggung dalam Al Qur'an surat alBaqarah ayat 280: "Dan jika (orang yang berhutang itu) dalam kesukaran, Maka berilah tangguh sampai Dia berkelapangan. dan menyedekahkan (sebagian atau semua utang) itu, lebih baik bagimu, jika kamu mengetahui."4

Maka dari sini qarḍ yaitu pinjaman atas uang atau suatu barang, yang harus dikembalikan pada waktu yang telah ditetapkan sesuai dengan jumlah ketika peminjaman, ketika terdapat potongan biaya administrasi dan tambahan saat pengembalian maka, tambahan tersebut diperbolehkan jika hanya sebatas

\footnotetext{
${ }^{4}$ Al-Qur'an, Al-Baqarah:280
}

pemebrian hadiah atau sebagai rasa terimakasih kepada yang telah memberi pinjaman. jika potongan biaya administrasi dan tambahan tersebut direncanakan dan menjadi salah satu syarat bagi peminjam untuk bisa mendapat pinjaman, maka hukumnya dilarang dan termasuk dalam riba'.

Sedangkan di Desa Karang Budi, Kecamatan Gapura, Kabupaten Sumenep, ada yang berbeda dengan praktek qard nya. Qard yang dilakukan oleh masyarakat yang tergabung dalam gabungan kelompok tani Desa Karang Budi, yaitu Kelompok Tani Anyar Tani di Desa Karang Budi, Kecamatan Gapura, Kabupaten Sumenep. Mereka berutang untuk memenuhi kebutuhan produksi pertanian, untuk pembelian pupuk, dan pembelian bibit unggul. Karena pada masa itu hampir semua masyarakat tidak ada pemasukan dana untuk biaya produksi karna masih awal musim tanam. Jadi, gabungan kelompok tani ini sangat membantu masyarakat di Desa tersebut. Ketika terjadi akad qarḍ (utang-piutang) dengan waktu pengembalian yang telah ditentukan, para peminjam dikenakan biaya administrasi dari jumlah yang sudah dipinjam, secara otomatis biaya tersebut adalah beban yang ditentukan ketika terjadi akad. Semisal si fulan meminjam sebesar Rp.100.000,00 namun pihak pengelola hanya memberi Rp.95.000,00 setelah dipotong biaya administrasi. namun pada saat waktu pengembalian peminjam harus mengembalikan sebesar Rp.100.000,00. dalam jangka waktu delapan bulan, dengan asumsi bahwa biaya administrasi tersebut nantinya difungsikan sebagai kepentingan anggotanya seperti untuk dana tambahan pembelian daging qurban, dana kematian, dana bantuan bagi warga yang membutuhkan bantuan di Desa Karang Budi, Kecamatan Gapura Kabupaten Sumenep. Berangkat dari latar belakang di atas, maka perlu diadakan penelitian lanjutan serta menganalisa kembali bagaimana tinjauan hukum Islam mengenai praktik qarḍ yang dilakukan 
sedemikian rupa di Desa Karang Budi, Kecamatan Gapura Kabupaten Sumenep.

Penelitian ini bersifat deskriptif karena data-data yang didapat dari lapangan berupa kata-kata yang ditulis oleh peneliti, penyajian gambar baik itu dari hasil wawancara, dokumentasi maupun observasi dan bukan berupa angka. Sedangkan bentuk penyajian datanya berupa kualitatif yaitu dengan pertimbangan menyesuaikan metode kualitatif lebih mudah dilakukan bila berhadapan dengan kenyataan ganda. Sehingga jenis penelitian ini termasuk dalam kategori jenis penelitian deskriptif kualitatif.

Dalam penelitian ini, pendekatan yang digunakan oleh peneliti adalah metode studi kasus. Penelitian studi kasus yang dikemukakan oleh Yin adalah sebuah metode penelitian yang secara khusus menyelidiki fenomena kontemporer yang terdapat dalam konteks kehidupan nyata, yang dilaksanakan ketika batasan-batasan antara fenomena dan konteksnya belum jelas dengan meggunakan berbagai sumber data 5 jadi penelitian studi kasus merupakan penelitian yang mengungkap permasalahan, peristiwa atau fenomena yang terjadi dilapangan yang berhubungan langsung dengan kehidupan individu maupun kelompok. kemudian dalam kasus atau perustiwa akan dikaji dari berbagai teori atau keilmuannya

Jenis data yang digunakan oleh peneliti adalah data primer. data primer merupakan jenis data yang dikumpulkan dan diolah peneliti secara langsung dari lapangan, melalui observasi dan interview yang berupa informasi melalui wawancara kepada pihak pelaku, berbagai tokoh masayarakat dan tokoh agama tentang sistem hutang piutang anggota kelompok tani di Desa Karang Budi Kecamatan Gapura Kabupaten Sumenep.

Subyek penelitian berupa informan yang akan di minta keterangannya tentang

\footnotetext{
${ }^{5}$ Imam Gunawan, Metode Penelitian Kualitatif; Teori Praktik, (Jakarta Bumi Aksara 2013)
}

obyek yang akan diteliti. Para informan tersebut diantaranya adalah pelaku dari praktek hutang piutang dalam kelompok tani dan sebagian tokoh masyarakat atau tokoh agama yang ada ditempat penelitian.

Sedangkan obyek penelitian adalah praktek utang piutang (Al-Qard) kelompok tani di Desa Karang Budi Kecamatan Gapura Kabupaten Sumenep, serta bagaimana tanggapan masyarakan dan tokoh agama terhadap praktek utang piutang tersebut.

Demi tercapainya tujuan dari sebuah penelitian, diperlukan beberapa sumber data sebagai berikut :

1) Sumber Data Primer

Yaitu pengolahan sumber data yang dikumpulkan oleh peneliti secara langsung dari lapangan, melalui observasi dan interview berupa informasi melalui wawancara kepada pihak pelaku, berbagai tokoh masayarakat dan tokoh agama tentang praktek utang piutang kelompok tani di desa Karang Budi Kecamatan Gapura Kabupaten Sumenep.

2) Sumber Data Sekunder

Yaitu sumber data yang dijadikan acuan landasan teori dalam pembahasan seperti buku-buku, karya ilmiah dan sumber-sumber lainnya yang relevan dengan pembahasan objek permasalahan dari penelitian.

metode yang digunakan oleh peneliti untuk mendapatkan dan mengumpulkan data dalam penelitian diantaranya :

Adalah teknik pengumpulan data yang digunakan peneliti untuk mendapatkan keterangan-keterangan lisan melalui bercakap-cakap dan bertatap muka dengan orang yang dapat memberikan keterangan.kepada peneliti. $^{6}$ Jenis wawancara yang digunakan adalah wawancara mendalam, dimana tujuannya untuk memperoleh bentuk-bentuk informasi dari semua responden, tetapi

${ }^{6}$ Dedy Mulyana, Metodologi Penelitian Kualitatif; Paradigma baru Ilmu Komunikasi dan Ilmu sosial lainnya, (Bandung : Remaja Rosdakarya, 2004) 
susunan dan urutan kalimatnya disesuaikan dengan ciri-ciri responden. ${ }^{7}$ Jadi, hal pertama yang dilakukakn oleh peneliti dalam mengumpulkan data adalah dengan melakukan wawancara dengan narasumber secara langsung. Data yang akan peneliti tanyakan adalah hal-hal yang berkaitan dengan praktek utang piutang pada kelompok tani di desa Karang Budi Kecamatan Gapura Kabupaten Sumenep. Menurut Suharsimi Arikunto, Observasi adalah suatu metode pengamatan dan pencatatan secara sistematis mengenai fenomena-fenomena yang diselidiki atau diteliti baik itu secara langsung maupun tidak langsung. ${ }^{8}$ Observasi yang dilakukan oleh peneliti adalah observasi non partisipan, dimana peneliti tidak akan ikut berperan serta ambil bagian dalam kehidupan subjek penelitian. Peneliti hanya akan mengadakan observasi menurut fenomena yang terjadi di lapangan dengan cara mengungkapkan secara cermat dan tepat melalui tulisan, dari hasil observasi tersebut kemudian dicatat dan diolah menjadi sebuah laporan penelitian. Data yang akan dikumpulkan dalam observasi ini seperti bagaimana konsep atau sistem yang dijalankan oleh masyarakat Desa Karang Budi tentang praktek hutang piutang anggota kelompok tani tersebut.

Metode ini dilakukan untuk memperoleh data yang tidak dapat digali dengan menggunakan metode tertulis yang mengandung keterangan dan penjelasan serta pemikiran tentang fenomena yang masih ada. Dalam hal ini bisa berupa gambar, arsip, maupun dokumen penting yang ada Desa Karang Budi Kecamatan Gapura Kabupaten Sumenep yang berhubungan dengan permasalahan dalam penelitian.

\footnotetext{
${ }^{7}$ Ibid.,

${ }^{8}$ Suharsimi Arikunto, Prosedur Penelitian; Suatu Pendekatan Praktek, (Jakarta: Rineka Cipta, 1991), 189
}

Teknik Pemeriksaan Keabsahan Data yang digunakan oleh peneliti adalah Trianggulasi. adapun yang dimaksud trianggulasi adalah teknik pemeriksaan keabsahan data yang memanfaatkan sesuatu yang lain di luar data untuk keperluan pengecekan atau sebagai alat pembanding terhadap data itu sendiri. Teknik trianggulasi yang digunakan adalah trianggulasi sumber. Yaitu membandingkan dan mengecek balik derajat kepercayaan suatu informasi yang diperoleh dengan alat yang berbeda dalam penelitian kualitatif. Hal ini bisa dilakukan dengan cara :

1) Membandingkan data hasil wawancara dengan hasil pengamatan.

2) Membandingkan hasil wawancara dengan dokumen lain.

Jadi trianggulasi merupakan cara terbaik untuk menghilangkan perbedaanperbedaan konstruksi kenyataan yang ada dalam konteks suatu studi sewaktu mengumpulkan data tentang berbagai kajian dan hubungan dari berbagai pandangan. Untuk itu maka peneliti dapat melakukannya dengan cara :

1) Mengajukan berbagai macam variasi pertanyaan.

2) Mengeceknya dengan berbagai sumber data.

Pada tahap ini, data yang didapat dikerjakan dan dimanfaatkan sedemikian rupa agar dapat menyimpulkan kebenarankebenaran yang dipakai untuk menjawab persoalan-persoalan yang diajukan dalam penelitian. Peneliti menggunakan analisis data model alur Miles dan Huberman, dimana dalam menjelaskan analisis data mempunyai tiga alur yaitu :

1) Reduksi data, yaitu proses pemilihan data, menggolongkan, mengarahkan, membuang yang tidak perlu dan mengorganisasikan data dengan cara sedemikian rupa hingga kesimpulan dan verifikasi.

2) Penyajian data. Dalam alur ini seluruh data-data di lapangan yang berupa dokumen, hasil wawancara dan hasil observasi akan dianalisis sehingga 
dapat memunculkan deskripsi tentang praktek utang piutang pada kelompok tani di desa Karang Budi Kecamatan Gapura Kabupaten Sumenep.

3) Penarikan kesimpulan adalah hasil akhir dari proses analisis data, dimana peneliti akan mendeskripsikan, menganalisa dan menginterpretasikan data yang peneliti dapatkan melalui penelitian tersebut diatas.

Dalam Analisis data, peneliti menggunakan metode deskriptif kualitatif dimana dalam melakukan penelitian, peneliti akan mencoba mendeskripsikan fakta dari semua hasil penelitian di lapangan, menganalisa dan menginterpretasikannya sehingga penelitian ini dapat diketahui kebenaran konsep dari praktek utang piutang pada kelompok tani di desa Karang Budi Kecamatan Gapura Kabupaten Sumenep.

\section{PEMBAHASAN}

1. Praktek utang piutang kelompok tani anyar tani desa karang buddhi kecamatan gapura kabupaten sumenep.

Meminjamkan uang/barang dengan tujuannya untuk saling tolong menolong sangat diperbolehkan. Qard yang berarti memberikan pinjaman tanpa menghendaki adanya lebihan dari uang yang dipinjamkan termasuk akad ta'awwun karena memberikan kepada masyarakat kecil dalam hal membantu mencukupi kebutuhannya.

Sebuah organisasi Kelompok Tani yang diberi nama Anyar Tani terletak di Desa Karang Buddhi Kecamatan Gapura Kabupaten Sumenep, menawarkan konsep pinjaman uang yang bersumber dari dana tabungan anggota untuk kemaslahatan para anggotanya. dimana para anggota tersebut yang meminjam uang dalam pengembalian utang tersebut, harus ada uang lebihan sebesar $10 \%$.

Prosedur atau sistem utang piutang yang dilakukan bisa dijelaskan sebagai berikut. Jika ada petani yang tergabung dalam Kelompok Tani Anyar Tani yang membutuhkan pinjaman, maka bisa meminjam di organisasi ini. Ketika meminjam uang sejumlah Rp.500.000.00 akan diberikan uang pinjaman sebesar Rp.450.000.00 peminjam tersebut harus mengembalikan sebesar Rp.500.000.00 dalam kurun waktu sepuluh (10) minggu peminjam harus sudah melunasi pinjamannya kepada kas Kelompok Tani. Sumatwi, ketua Anyar Tani juga menambahkan, "Pinjam Rp.500.000.00 diberi pinjaman Rp.450.000.00 karena telah dipotong oleh biaya administrasi dan amggota tersebut harus mengembalikan sejumlah Rp.500.000.00 dan apabila Pinjam Rp.1.000.000 diberi pinjaman RP.950.000.00 harus mengembalikan sejumlah Rp.1.000.000.009 Sebagai contoh lagi, ketika $\mathrm{Si}$ Budi meminjam uang sebesar Rp. 300.000.00 kepada kelompok Anyar Tani, pengurus hanya memberi pinjaman senilai Rp. 250.000.00 setelah dikurangi biaya administrasi dan dalam jangka waktu sepuluh (10) Minggu Budiman harus mengembalikan sebesar Rp. 300.000.00.

Dalam memberi pinjaman, Pengurus Anyar Tani juga melihat dan mempertimbangkan kondisi anggotanya. jika kondisi anggotanya baik, mampu mengembalikan tepat waktu, maka bisa diberikan pinjaman. Karena pengurus Kelompok Anyar Tani sudah memahami bagaimana karakter para anggotanya yang berada dalam lingkup desa Karang Buddhi, namun jika karakter peminjam memiliki citra yang diketahui tidak baik, oleh pengurus Anyar Tani, maka kelompok tani tidak akan memberi pinjaman untuk yang kedua kalinya. Karakter dan kondisi peminjam yang baik dari tiap anggota menjadi alasan pengurus Anyar Tani untu dapat memberikan pinjaman lagi tiap kali anggotanya membutuhkan pinjaman. ${ }^{10}$

\footnotetext{
${ }^{9}$ Sumatwi, Wawancara, Sumenep 29

Agustus 2018

10 Ibid.,
} 
Ketika pada musim tanam, sering kali kelompok Anyar Tani mengalami kekurangan dana kas, dikarenakan meningkatnya jumlah petani yang melakukan peminjaman dana kas. ${ }^{11}$ ketika musim tanam, uang kas sering habis dan kosong karena petani banyak yang meminjam untuk kepentingan pembelian pupuk, bibit padi, pembasmi hama, "mes" 12 , ini sebab dana kas sering kosong, belum lagi ketika petani mengalami gagal tanam, ini menjadi problem pengembalian pinjaman. Jika masalah tersebut terjadi, gapoktan menyiasati dengan cara, petani yang memiliki sisa tabungan dalam arisan, akan dipotong untuk menutupi pembayaran pinjamannya. petani yang memiliki utang pada saat giliran untuk memperoleh uang arisan, maka uang tersebut tidak akan diberikan (atas izin dan sepengetahuan pemilik uang) hal ini dilakukan untuk melunasi sisa utangnya kepada pengurus Anyar Tani. Demikian cara yang digunakan dalam pembayaran utang, sehingga dana kas akan terus ada dan terkelola dengan baik. Yang diperbolehkan untuk melakukan peminjaman pada Kelompok Tani hanyalah anggota yang latarbelakang pekerjaannya adalah Petani. Anggota dari Kelompok Tani Anyar Tani berjumlah 30 orang termasuk pengurusnya, dan setiap orang membayar kas Rp.5.000.00/ minggu sebagai modal awal dari uang kas Kelompok Tani.

a. Uang lebihan dari utang piutang untuk kepentingan anggota.

Dalam sistem utang piutang yang dilakukan oleh Kelompok Tani Anyar Tani Desa Karang Buddhi Kecamatan Gapura Kabupaten Sumenep ini, memiliki sistem pemotongan sebesar $10 \%$ dari dana pinjaman, pada saat pengembalian ada lebihan yang disepakati oleh pihak peminjam dan pemberi pinjaman sejumlah $10 \%$.
Kewajiban pagi pihak peminjam harus membayar lebihan utangnya, kepada Kelompok Tani. Semisal dalam utang piutang ini ketika ada yang meminjam sebesar Rp.500.000.00 hanya diberikan uang sebesar Rp.450.000.00. Sedangkan lebihan pengembalian yang disepakati sebesar $10 \%$ dari pinjaman yaitu sebesar Rp.50.000. dari Jumlah Rp.50.000.00 tersebut akan digunakan sebagai kepentingan sosial. Ketua Kelompok Anyar Tani Sumatwi, menyebutnya sebagai dana sosial, dimana uang lebihan tersebut nantinya akan dipergunakan untuk kepentingan sosial dilingkungan para anggotanya. seperti dana bantuan pupuk, dana kerja bakti Kelompok Tani, untuk dana tambahan pembelian daging sapi yang akan dibagikan kepada anggota saat Hari Raya Idul Fitri, sebagai dana sosial ketika ada warga yang sakit atau meninggal. ${ }^{13}$

2. Anilisis Utang Piutang Anggota Kelompok Tani (Studi Kasus Di Desa Karang Budi Kecamatan Gapura Kabupaten Sumenep).

Permasalahan tentang pemberdayaan ekonomi umat sering di lakukan oleh pemerintah maupun organisasi yang di kategorikan sebagai lembaga swadaya masyarakat maupun lembaga keuangan, salah satu yang ada di Desa Karang Buddhi adalah kelompok tani bernama Anyar Tani yang memberikan layanan utang piutang bagi anggotanya yang membutuhkan, namun untuk memahami dan mengetahui apakah usaha utang piutang pada Kelompok Tani Anyar Tani di Desa Karang Buddhi ini sudah sesuai dengan hukum Islam atau sebaliknya, justru bertentangan, maka peneliti melakukan analisis hukum Islam terkait qard yang ada pada kelompok tani Anyar Tani di Desa Karang Buddhi Kecamatan Gapura Kabupaten Sumenep. analisis yang dilakukan terpusat pada beberapa hal, antara lain:

${ }^{13}$ Wawancara, Moh.Imam, Sumenep 29 Agustus 2018
11 Ibid.,
12 "Mes" (Pupuk Organik) 


\section{a. Tujuan Qard}

Dalam kelompok tani Anyar Tani Desa Karang Budhhi, dana qard diberikan dengan bertujuan untuk membantu para anggotanya yang memerlukan dana cepat, yaitu dana untuk anggota yang memerlukan dana untuk biaya kebutuhan sehari-hari, biaya sekolah anaknya, untuk biaya tambah modal usaha, dana untuk pembelian perlengkapan pertanian dan lain sebagainya. Dalam hukum Islam tujuan qarụ adalah untuk memberi pinjaman tanpa imbalan, karena jika terdapat imbalan atau lebihan yang disepakati, termasuk dalam riba yang diharamkan oleh syariat Islam, seperti dalam hadist yang berbunyi:

"dari Malik r.a dia berkata: pernah disampaikan orang kepadaku bahwa seorang laki-laki pernah datang kepada Abdullah Bin Ummar supaya melebihi jumlah yang telah aku utangkan kepada seseorang dan telah aku syaratkan atasnya, lalu orang itu berkata : sesungguhnya aku telah mengutangkan kepadanya, maka Abdullah Bin Ummar berkata, "yang demikian itu adalah riba"

Dalam hadis tersebut dijelaskan, kelebihan dalam utang/qard yang diperbolehkan oleh syariat islam adalah kelebihan yang diberikan karena keinginan sendiri, tetapi kalau diakadkan lebih dahulu atau ditentukan besarnya terlebih dahuhlu oleh orang yang mengutangkan, lebihan itu hukumnya menjadi riba dan itu dilarang oleh agama. Sedangkan dalam aplikasinya di Kelompok Tani Anyar Tani, cara pengembalian pinjaman qard nya yakni mengurangi jumlah pinjaman yang diajukan sebagai biaya administrasi $10 \%$ dan menambahkan jumlah nominal pinjaman sebagai lebihan sebanyak $10 \%$ sesuai kesepakatan diawal akad, sebagai keuntungan di Kelompok Tani karena telah memberikan pinjaman. Hal ini sudah berbeda dengan tujuan qard dalam hukum Islam. Selain itu tujuan qard juga tidak boleh semata untuk kepentingan komersialisasi karena bisa dijadikan sarana untuk memperbanyak keutungan semata. Dalam setiap muamalah dan transaksi, pada dasarnya didalam Hukum Islam diperbolehkan, seperti halnya dengan utang-piutang, kecuali yang jelas diharamkan seperti mengakibatkan kemudharatan, tipuan, judi dan riba.

\section{b. Shigot}

Shighot yaitu ijab dan qabul. Sebagian ulama Syafi'iyah berpendapat, jika peminjam berkata kepada pemberi pinjaman, "berikanlah saya utang sekian". Lalu dia meminjaminya; atau peminjam mengirim seorang utusan kepada pemberi pinjaman, lalu ia mengirim sebuah harta kepadanya, maka akad qard tersebut sah. Menurut Al-Adzrai, ijma ulama sepakat sistem tersebut sah dilakukan.

Dalam prakteknya pada Kelompok Tani perjanjian antara pihak Pengurus dan anggota sama-sama sepakat memberi pinjaman dan menerima pinjaman. Hal itu terlihat ketika pihak pengurus Kelompok Tani Anyar Tani memberikan pinjaman kepada anggotanya, sedangkan dari pihak anggota menerima pinjaman tersebut dengan perjanjian sanggup mengembalikan dikemudian hari sesuai tenggang waktu yang diberikan dan ditambah dengan laba yang telah ditentukan diawal akad.

Akan tetapi dalam shigat pelaksanaan qard Kelompok Tani Anyar Tani di Desa Karang Buddhi ada yang berbeda, yaitu ketika peminjam meminjam uang sebesar Rp. 500.000.00 pengurus hanya memberi pinjaman sebesar Rp. 450.000.00, ini tidak sesuai dengan shighat yang ada, pada dasarnya jika peminjam meminjam sebesar Rp. 500.000 maka uang yang seharusnya diberikan juga Rp. 500.000 .

3. Tinjauan Hukum Islam Terhadap Praktek Utang Piutang Anggota Kelompok Tani (Studi Kasus Di Desa Karang Budi Kecamatan Gapura Kabupaten Sumenep). 
Kekayaan/harta adalah salah satu bentuk karunia Allah di Bumi yang diberikan kepada hambanya untuk dijadikan sarana beribadah. dan adanya keinginan untuk membelanjakan harta tersebut dijalan yang dibenarkan dengan syariat. Salah satunya dengan cara saling membantu sesama yang membutuhkan, dalam hal ini memberi utang bagi yang membutuhkan pinjaman uang dikenal sebagai istilah qarḍ, akan tetapi tidak diperbolehkan memberi pinjaman yang bisa membebani peminjam dikarenakan syarat yang cukup berat.

Didalam lingkungan perbankan syari'ah, qarḍ bukan sebagai transaksi komersial, maka pada praktiknya tidak boleh mengambil keuntungan baik tambahan atau manfaat apapun bentuknya kecuali hanya untuk biaya administrasi. Pada saat pelunasan pun tidak boleh ada kelebihan yang disepakati meski tujuannya demi kepentingan sosial, ini dikarenakan kelebihan yang disepekati dari pengembalian utang adalah termasuk riba.

Fatwa Dewan Syari'ah Nasional NO: 19/DSN MUI/IV/2001 berisi tentang qard yang memperbolehkan bagi pemberi pinjaman agar membebankan biaya administrasi kepada nasabah. Nasabah dalam hal ini adalah peminjam/anggota. Akan tetapi, dalam penetapan besarnya biaya administrasi sehubungan dengan pemberian qard, tidak boleh berdasarkan perhitungan persentasi dari jumlah dana qarḍ yang diberikan. ${ }^{14}$ Sebagaimana contoh ketika peminjam meminjam uang sejumlah Rp.500.000.00 maka peminjam harus memberi dana qard sejumlah Rp.500.000.00 pula, tidak boleh meberi hanya Rp. 450.000.00 dengan dalih yang RP.50.000.00 masuk sebagai dana administrasi. Jika mengharuskan adanya administrasi yang harus dibayarkan oleh peminjam, jumlah tersebut dihitung sendiri, tidak termasuk nominal yang

\footnotetext{
${ }^{14}$ Dewan Syariah Nasional MUI,
} Himpunan Fatwa Keuangan Syariah, (Erlangga: 2014)., 132 diajukan peminjam. Peminjam utuh menerima jumlah dana qard sejumlah Rp. 500.000 ,- tanpa adanya potongan biaya administrasi. itula yang dimaksud dalam fatwa Dewan Syariah Nasional diatas. Sedangkan fenomena yang terjadi dalam praktek qard Kelompok Tani di Desa Karang Buddhi, jumlah administrasi menjadi satu dalam hitungan uang yang diajukan oleh peminjam, maka praktek qard di desa Karang Buddhi yang dilakukan oleh Kelompok Tani tidak sesuai.

Sedangkan lebihan dana yang dibebankan kepada peminjam saat pembayaran, yang diterapkan pada Kelompok Tani difungsikan sebagai dana sosial, seperti pembelian bibit, pembelian pupuk, membantu anggota ketika ada yang sakit, pada hakikatnya lebihan tersebut termasuk riba, karena lebihan yang disepakati diawal transaksi utang piutang dilarang dalam sistem muamalah, sehingga transaksi dalam bentuk apapun tidak boleh mengandung unsur riba, unsur yang dilarang (diharamkan) dalam syariat Islam. Dari berbagai macam pertimbangan dan analisis, maka praktek qard/utang piutang Kelompok Tani Anyar Tani di Desa Karang Buddhi Kecamatan Gapura Kabupaten Sumenep bertentangan dengan syariat Islam, karena sistem pelaksanaannya tidak sesuai dengan prinsip muamalah dan bertentangan dengan syariat Islam. Di dalam prakteknya juga terdapat unsur riba yang diharamkan dalam al-Quran dan Hadits, terdapat juga sistem administrasi yang tidak sesuai dengan fatwa Dewan Syari'ah Nasional (DSN), karena hitungan administrasi yang dibebankan presentase jumlah uang yang diutangkan, kemudian shigotnya juga tidak sesuai, karena antara uang yang dipinjam dengan uang yang diberikan dari pengurus Kelompok Tani selaku pemberi pinjama kepada kepada anggota/peminjam tidak sesuai jumlahnya. Jika memang dibutuhkan usaha dalam hal keuangan, yang hendak difungsikan untuk kepentingan sosial, maka dapat dilakukan 
dengan membuka sarana usaha lain, bukan mengatasnamakan utang piutang (qard) karena akad dalam utang-piutang adalah tabarru'. tidak untuk mencari keuntungan, atau komersialisasi meskipun mengatas namakan untuk kepentingan sosial cara tersebut tetap tidak dibenarkan dalam syari'at Islam. Menghasilkan uang dari jalan dan sistem yang tidak benar, dengan alasan untuk kepentingan sosial tidak pernah dibenarkan. Terlebih jika di dalamnya menyebabkan terjadinya riba', pembodohan, pembohongan atau manipulasi, justru semakin jauh dari tujuan, aturan, serta akad utang-piutang yang disyari'atkan Islam.

\section{KESIMPULAN}

Qarḍ yaitu pinjaman suatu barang ataupun uang yang harus dikembalikan pada waktu yang telah ditetapkan sesuai dengan jumlah ketika saat peminjaman, jika terdapat penambahan yang disepakati bersama diawal perjanjian dan menjadi salah satu syarat bagi peminjam untuk bisa mendapat pinjaman, maka hukumnya dilarang dan termasuk dalam riba. Jumlah pemberian uang pinjaman yang tidak sesuai jumlahnya mendapatkan potongan biaya administrasi, juga bertentangan dengan Fatwa Dewan Syariah Nasional, disamping itu terdapat unsur mencari keuntungan yang bertentangan dengan sistem utang piutang, karena pada dasarnya meminjamkan untuk saling tolong-menolong', bukan mencari keuntungan semata serta tanpa mengharap imbalan.

Terdapat unsur riba dalam praktek utang piutan pada kelompok tani di Desa Karang Buddhi, karena adanya lebihan pengembalian yang disepakati dan disyaratkan bagi peminjam diawal akad, jelas hal ini tidak diperbolehkan dalam hukum Islam, meskipun dengan alasan untuk kepentingan sosial. Tidak dibenarkan mengambil keuntungan serta mengatasnamakan kepentingan sosial dengan cara yang dilarang dan bertentangan dengan syariat islam.

\section{DAFTAR PUSTAKA}

Asmuni Bisnis Syariah Suatu alternative Pengembangan Bisnis yang Humanistik dan Berkeadilan. Medan : Perdana Publishing. 2016

Abdullah, Makruf. Manajemen Bisnis Syariah. Yogyakarta : Aswaja Pressindo. 2014.

Antonio, Muhammad Syafi'i. Bank Syariah Dari Teori Ke Praktik. Jakarta : Gema Insani. 2001.

Bungin, Burhan. Metodologi penelitian Sosial dan Ekonomi. Jakarta : Kencana Prenada Media Group. 2013.

Misbach, Muh Kholid. Pendidikan kemuhammadiyah. Surabaya : Majelis Dikdasmen PWM Jatim. 2013.

Hadi, Abd. Memahami akad-akad Perbankan syari'ah dan DasarDasar Hukumnya. Surabaya. Sinar Terang. 2015.

Supriyatna, dadang. Manajemen. Tangerang Selatan. Universitas Terbuka. 2015.

Andriyanto. Buku Ajar Manajemen Bank Syariah, Surabaya. UMSurabaya publishing. 2017.

Rivai, Veithzal. Islamic Economics Ekonomi Syariah Bukan Opsi, Tetapi Solusi. Jakarta. Bumi Aksara. 2013.

Sugiyono. Metode Penelitian Administrasi. Bandung: Alfabet. 2012.

Alfan, Kamaluddin. Etika Manajemen Islam, Bandung ; Pustaka setia.2001.

Bugha (al), Musthofa Dib, Fiqh Al Mu'awwadah, Jakarta : Hikmah, 2009.

Sarwat, Ahmad, Fiqih Muamalah, Jakarta : Kampus syariah, 2009. 